\section{National Preparedness Month - September 2016}

Throughout September, CDC and approximately 3,000 global, national, regional, and local government organizations, as well as private and public institutions, will promote the importance of being ready for emergencies (1-3). For Preparedness Month 2016, CDC's Office of Public Health Preparedness and Response will focus on the power of preparedness globally and locally and actions that can be taken collectively and individually (1).

Being prepared saves lives. Public health emergencies might take the shape of an emerging or rapidly spreading disease, a natural disaster, or an act of bioterrorism. While the nature, timing, and location of the next threat cannot be anticipated, developing programs to prevent, detect, and respond to public health emergencies can mitigate the impact of the unknown (2). Persons can take action now by having a family reunification plan and an emergency kit with basic supplies, medicines, and local emergency telephone numbers.

During preparedness month, CDC's Public Health Matters blog (3) will feature stories about how countries are partnering to advance health security, how emergencies prompt innovation and training, how states respond to new disease threats, and how every person plays a powerful role in protecting our communities and families. Preparedness Month will include infographics, social media, and a Twitter chat on September $27 @$ @CDCEmergency. The month culminates with National PrepareAthon! Day on September 30. Additional information about CDC's Preparedness Month is available at http://www.cdc.gov/phpr/npm.

\section{References}

1. CDC. National preparedness month. Atlanta, GA: US Department of Health and Human Services, CDC; 2016. https://www.cdc.gov/phpr/npm

2. CDC. Global health security: international health regulations (IHR). Atlanta, GA: US Department of Health and Human Services, CDC; 2016. http://www.cdc.gov/globalhealth/healthprotection/ghs/ihr/index.html

3. CDC. Public health matters blog. Atlanta, GA: US Department of Health and Human Services, CDC; 2016. http://blogs.cdc.gov/publichealthmatters

\section{School District Crisis Preparedness, Response, and Recovery Plans - United States, 2012}

Brenda Silverman, $\mathrm{PhD}^{1}$; Brenda Chen, $\mathrm{MBBS}^{1}$; Nancy Brener, $\mathrm{PhD}^{2}$; Judy Kruger, $\mathrm{PhD}^{1}$; Nevin Krishna, MS, $\mathrm{MPH}^{1}$; Paul Renard, Jr, MS ${ }^{1}$;

Sandra Romero-Steiner, $\mathrm{PhD}^{3}$; Rachel Nonkin Avchen, $\mathrm{PhD}^{1}$

The unique characteristics of children dictate the need for school-based all-hazards response plans during natural disasters, emerging infectious diseases, and terrorism (1-3). Schools are a critical community institution serving a vulnerable population that must be accounted for in public health preparedness plans; prepared schools are adopting policies and plans for crisis preparedness, response, and recovery (2-4). The importance of having such plans in place is underscored by the development

\section{INSIDE}

954 Physical Inactivity Among Adults Aged 50 Years and Older — United States, 2014

959 Association Between User-Generated Commuting Data and Population-Representative Active Commuting Surveillance Data - Four Cities, 2014-2015

963 Implementation of a National Semen Testing and Counseling Program for Male Ebola Survivors Liberia, 2015-2016

967 Vital Signs: Disparities in Antihypertensive Medication Nonadherence Among Medicare Part D Beneficiaries — United States, 2014

977 Investigation of First Identified mcr-1 $^{-1}$ Gene in an Isolate from a U.S. Patient — Pennsylvania, 2016

979 Investigation of Escherichia coli Harboring the $\mathrm{mcr}-1$ Resistance Gene - Connecticut, 2016

Continued on next page.

Continuing Education examination available at http://www.cdc.gov/mmwr/cme/conted_info.html\#weekly.

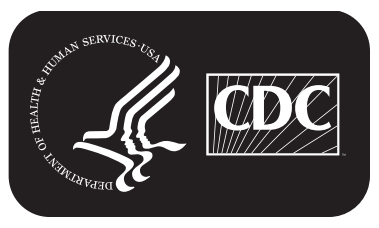

U.S. Department of Health and Human Services Centers for Disease Control and Prevention 